\title{
Quality of the relationship and menopausal symptoms of menopausal women
}

\section{BACKGROUND}

The aim of this study was to evaluate the occurrence and intensity of menopausal symptoms, taking into account the length of one's relationship, its nature and one's assessment of it.

\section{PARTICIPANTS AND PROCEDURE}

The study included 200 women between the ages of 45 and 68 , with secondary or higher education, married or in cohabiting relationships. Women were divided into three groups depending on the experience related to menopause: premenopause (46 respondents), perimenopause (75 respondents), and postmenopause (79 respondents). The study used a survey of self-design, the "Women's Health" Questionnaire (WHQ) by M. Hunter, and the "Partner Relations Questionnaire” (PFB) by K. Hahlweg.

\section{RESULTS}

Most menopausal symptoms - including those of the greatest severity - are experienced by women in perimenopausal and postmenopausal phases, but one's own relationship's assessment is the lowest in postmenopausal women. In this group of women, relevant and significant relations between the dimensions of the quality of the relationship and the menopausal symptoms are the most numerous. The most essential assessment was the one relating to intimacy - its poor evaluation is accompanied by higher intensity of experienced depression symptoms, somatic symptoms, and disorders of memory and concentration, sex and sleep, and also the sum of menopausal symptoms is higher. In all three groups, no significant differences in the severity of menopausal symptoms were observed between women in marital and cohabiting relationships. In women in the perimenopausal phase, the shorter the length of the relationship (its seniority), the greater is the severity of sexual dysfunction symptoms, whereas in women in the postmenopausal stage, along with the length of the relationship, the severity of psychological and somatic symptoms increases.

\section{CONCLUSIONS}

One should find that the perimenopausal and postmenopausal phases are particularly difficult for women, meaning that the intensity of menopausal symptoms is the greatest during them. The assessment of one's relationship's quality is relevant for the menopausal symptoms experienced. Women who perceive their relationship as more intimate report less severe menopausal symptoms. The type of relationship does not differentiate women with regards to their experience associated with menopause. Both shorter and longer seniority of the relationship may constitute a risk factor triggering an increase of the severity of menopausal symptoms.

\section{KEY WORDS}

premenopause; perimenopause; postmenopause; quality of the relationship

organization - Institute of Psychology, University of Lodz, Lodz, Poland

Authors' Contributions - A: Study design - B: Data collection - C: Statistical analysis - D: Data interpretation .

E: Manuscript preparation · F: Literature search · G: Funds collection

CORRESPONDING AUthor - Karolina Jarecka, Ph.D., Institute of Psychology, University of Lodz, 10/12 Smugowa Str.,

91-433 Łódź, Poland, e-mail: karolina.o.jarecka@wp.pl

TO CITE THIS ARTICLE - Jarecka, K., \& Bielawska-Batorowicz, E. (2017). Quality of the relationship and menopausal

symptoms of menopausal women. Health Psychology Report, 5(1), 55-66. doi: 10.5114/hpr.2017.62522

RECEIVED 14.02.2016 · REVIEWED 22.03.2016 · ACCEPTED 19.04.2016 · PUBLISHED 10.10.2016 


\section{BACKGROUND}

Most commonly, what gives meaning to life and where the source of happiness is believed to be are close, rewarding relations with others. The need of belonging is one of the basic human needs, which, when met, contributes to the well-being (Myers, 2007). A positive life balance to a greater degree depends on the fulfilment in the love relationship than on professional success at work. Job satisfaction appears to be of relevance, if accompanied at the same time by a positive assessment of one's relationship with one's partner (King, Ells, \& Burton, 2007).

Research (Janicka, 2012) indicates that single people function worse. Persons who are in close and satisfying emotional relationships are happier, they are better off as far as mental and physical health are concerned, and they live longer than single people (Kamp Dush \& Amato, 2005; Myers, 2007) by 2.3-2.8 years (Taylor \& Sherman, 2007).

A study conducted for 70 years at Harvard University has proven that good marriage (with spouses satisfied with their relations) has a more positive influence on the state of health of people in their 50s than low cholesterol level. Presumably, it is easier to take care of oneself, eat healthily, be physically active and systematically seek medical attention when one's partner motivates and exercises control over such activities. This increases the chances for pro-health behaviour. A study of 50000 adults showed that the frequency of smoking and alcohol use is significantly reduced after marriage (Myers, 2007). In addition, marriage may improve the functioning of the immune system. The emotional bond increases the resistance to viruses and colds, reduces blood pressure and stress hormone levels, and in case of an illness, it can provide for a faster recovery (Bishop, 2000; Waite \& Gallagher, 2000). Research related to the control of pro-health behaviour confirms that being in a marriage and mutual love stimulate the immune system, resulting in better health of the married persons (Argyle, 2005).

A close person is an invaluable source of emotion$\mathrm{al}$ and instrumental support, though at times the sole awareness that one has this support available is sufficient - so the certainty of the fact that help will come, and not what it would mean (Taylor \& Sherman, 2007). Support determines the meeting of significant human needs - the sense of security, being important, loved; it allows for better functioning in everyday life and coping with tough situations (Cutrona, 1996). The realization that one can count on somebody else's assistance protects from health deterioration and favours proper adaptation to difficult circumstance and life problems (Harwas-Napierała, 2012). Having a supportive partner allows one to more efficiently face challenges by eliminating or modifying the conditions creating the problem, change the meaning of the stimulus triggering stress, and organise the level of emotional reaction to stress (Tobiasz-Adamczyk, 2000). Persons who remain in stable and positive relationships less frequently sustain a high allostatic load, meaning the accumulation of adverse changes in systems regulating biological stress which is the effect of prolonged exposure to a chronic or recurring stressor. Support from others lowers the psychological discomfort in harsh life situations, reducing negative emotions, such as anxiety, and facilitates adapting to the changed and stress-triggering circumstances. Such concatenations concern a number of disorders, including coronary artery disease, diabetes, HIV infection, cancer and rheumatoid arthritis. Relationships with people seem more relevant to the incidence of chronic disease and mortality than other recognised risk factors, such as smoking, obesity or lack of physical activity (Taylor \& Sherman, 2007).

The support one receives from one's partner favourably influences one's health, and allows one to better endure the hardships of life and deal with periods of crucial change which are characteristic for menopause. The term "menopause" was introduced to the scientific literature in 1816 by the French physician C. de Gardanne to determine the "critical" age in a woman's life (Bielawska-Batorowicz, 2011). Menopause is the name of the last menstrual period in a woman's life. It is recognised only after 12 months during which there has been no menstrual bleeding and is caused by the decline in the hormonal activity of the ovaries (Bińkowska, 2011). It appears irrevocably in every woman's life, and it means the loss of the ability to procreate and several, usually perceived negatively, changes in psychological and somatic functioning (Bielawska-Batorowicz, 2006). The average age for Polish women for menopause to start is between 48 and 52 years, but the general range is wider, from 46.6 to 55 years of age (Kaczmarek, 2007). The age for reaching menopause for women in Poland may be linked to the age of menarche (the first occurrence of menstruation), menstrual cycle length, number of births given and the use of contraceptives (Kaczmarek, 2008). The menopausal period (climacterium) is one of the hormonal changes related to these successive phases: premenopause (the span of ca. 2-4 years before the last menstrual period), perimenopause (immediate stage before menopause, extending to 1 year after the menopause has started - the time of irregular menstruation cycles) and postmenopause (the term after the menopause) (Raport WHO, 2001; Bińkowska, 2011).

The main cause of the occurrence of menopausal symptoms, which include somatic and psychosomatic symptoms, is the progressive decrease in ovarian hormonal activity, but also intensifying involution changes, other endocrinological disorders and stress associated with the change of socio-economic situation. These factors account for the differences in the perceived severity of symptoms (Stachon, 2013). Experts of the World Health Organization divide the 
menopausal symptoms into symptoms specific to this phase (linked to hormonal changes) - vasomotor and urogenital symptoms, irregular menstruation - and symptoms non-specific for the menopause (symptoms which may be caused by factors other than hormonal changes), for example depression, nervous tension, insomnia, difficulty in concentration, headaches, dizziness, back pain, and a decrease in energy (Raport WHO, 2001). Non-hormonal factors which may cause nonspecific symptoms include financial status, family and work-related situations, education, aging and stimulant use, e.g. smoking (Bielawska-Batorowicz, 2006).

The changes that women experience during menopause and which are described as difficult apply not only to the functioning of the body but also its appearance, professional activity and family life. In societies where the cult of youth predominates, menopause is seen purely as a time of loss. Older women may be unfavourably judged as persons with an unattractive appearance and changes in behaviour - hence the negative attitude of women towards menopause, which is a sign of aging. Studies suggest that menopause undermines the sense of identity determined by age and attribution of symptoms (Schneider, MacLennan, \& Feeny, 2008). Therefore, the most significant element of aid is receiving information that one is valued, surrounded by attention, concern and love, and that one belongs to a network of common relationships and mutual bonds (Tobiasz-Adamczyk, 2000). Menopause is evaluated negatively by women who do not endure this period well. Usually this pertains to women who suffer from chronic diseases, who had ailments associated with menstruation (premenstrual syndrome), live in constant stress, have a negative attitude towards aging (Fuh, Wang, Lee, Lu, \& Juan, 2003; Bielawska-Batorowicz, 2006), lead an unhygienic lifestyle and have bad relationships with their partners (Barth Olofsson \& Collins, 2000).

The results of Western (Waite \& Gallagher, 2000; Argyle, 2005) and Polish (Janicka, 2008) research report that the two forms of stable relationships marriage and cohabitation - are not equivalent in terms of the given and received support as well as the sense of security of the partners. It is believed that the strongest correlate of welfare, due to the involvement of partners, is marriage (Farrel, Hook, \& Ramos, 2015). Marriage proves to be invaluable in stressful situations. Partners through a sense of connectedness and bond perceive problems as affecting them jointly. They share mutual support, which is continuous, i.e. it is there always (not occasionally). Married couples obtain higher scores on satisfaction with their relationships than cohabiting couples because with the latter the support, being usually possible, is not treated as obligatory (Argyle, 2005; Janicka, 2012). One of the Western studies found that women in menopause - regardless of their race and ethnicity
- who are married experience lower levels of stress and assess their quality of life as higher (Avis, Assmann, Kravitz, Ganz, \& Ory, 2004). Such dependencies between marriage and well-being are present in all countries. Furthermore, it is the simplicity in exiting the relationship that makes people less satisfied with them. Irrevocable choices bring more joy than those from which you can easily withdraw (Myers, 2007).

The time of hormonal changes which falls into the second half of the average adulthood is also a difficult time for the functioning of the relationship. What may happen here is people parting ways or strengthening their relationship. The increase in freedom resulting from fewer responsibilities as a parent can lead to weakening the need to identify with marriage and surrender one's personal interests to it, as well as the temptation of regaining complete autonomy (Oleś, 2000). Spouses gain more time for other, non-family related activities and can focus on personal fulfilment. A big change in the functioning of one partner may be perceived as a threat by the other one. In addition, the life balance which is made in this period, when negative, can lead to blaming one's spouse, which poses a threat to the relationship (Grabowska, 2014). On the other hand, it may be a period for the couple's relations to mature, contributing to a satisfying further life together. The condition is to recognise the hitherto mutual achievements and to identify new common goals in line with the development period of partners. Common life, at this time, can also be a source of great experience and give a sense of happiness.

The aim of the study was to identify the importance of the relationship, its type and length together with the quality of relations with the partner for the incidence and severity of menopausal symptoms. The following research questions were formulated: Are there differences in the occurrence and severity of menopausal symptoms between the three groups of women, depending on the menopause phase: premenopausal, perimenopausal, postmenopausal? Does the type and length of the relationship decide on the severity of menopausal symptoms? Do these variables (type and length of the relationship) - which are treated as risk factors for severity of menopausal symptoms to increase - refer to the same extent to all groups of women? Are there differences in the assessment of one's relationship between the three groups of women? Is there a correlation between the occurrence and intensity of menopausal symptoms and the satisfaction with the relationship, the assessment of conflictual behaviours, mutual communication and intimacy in the relationship?

\section{PARTICIPANTS AND PROCEDURE}

The survey examined 200 women between the ages of 45 and 68, with secondary or higher education,
Quality of the relationship of menopausal women 
Karolina Jarecka, Eleonora BielawskaBatorowicz married or in cohabiting relationships. Due to the fact that after the $45^{\text {th }}$ year of age, some women begin to experience adverse symptoms related to the physical and mental sphere (Kaczmarek, 2007, 2008), the research also included this age group and assigned it to a risk group for menopause symptoms occurrence (premenopause). The study included patients up to 68 years of age, because nowadays people live longer, enjoy good health and remain active longer, including in the professional domain. Women were divided into three groups depending on the experience related to menopause (occurrence and regularity of menstruation). The first group comprised women in the premenopausal phase, hence with the risk of starting to experience menopausal symptoms (46 respondents); the second group comprised women during the perimenopausal stage, also called the transitional or "circa-menopausal" period (75 respondents); and the third group consisted of postmenopausal women (79 respondents). The women in the premenopausal phase ranged in age from 45 to 47 years, perimenopausal women were aged between 48 and 50, and those in postmenopause were between the ages of 51 and 68 .

In order to verify the questions posed in the study, the following research methods were applied: a survey of self-design, the "Women's Health" Questionnaire (WHQ) by M. Hunter, and the "Partner Relations Questionnaire" (PFB) by K. Hahlweg.

The survey designed for the purpose of this study was used to obtain demographic information on health and lifestyle. Additionally, it contained questions which helped to select the three groups of women: in premenopause (regularly menstruating), in perimenopause (irregularly menstruating) and postmenopause (not menstruating for more than a year).

The "Women's Health" Questionnaire (WHQ) by M. Hunter, in a Polish adaptation by Bielawska-Batorowicz, is used to measure the emotional and physical symptoms in women starting from the age of 45 . It is a tool for the evaluation of 36 symptoms related to mood, physical ailments, sexual experiences, vasomotor and menstrual symptoms. Individual claims form a scale: depressed mood, somatic symptoms, memory/concentration, vasomotor symptoms, anxiety/fears, sexual behaviour, sleep problems, menstrual symptoms - breast tenderness, cramps in the abdomen, the abundance of menstruation, abdominal distension and attractiveness. The higher the score in the given scale, the more difficulties and unpleasant experience occur in a given area. The "Women's Health" Questionnaire also allows one to calculate the total coefficient, which is the sum of all accumulated points. The accuracy of the questionnaire was confirmed by comparisons with the GHQ - General Health Questionnaire. The reliability determined by the Cronbach $\alpha$ value is in the range of .69-.96 (Hunter, 1992). The reliability of the test has also been evaluated for the results of the research presented in this work. The Cronbach $\alpha$ value is in the range from .80 to .86 .

The "Partner Relations Questionnaire" (PFB Partnerschaftsfragebogen) by K. Hahlweg, in a Polish adaptation by Janicka, is used to diagnose the quality of relations between spouses and between cohabiting partners. The questionnaire consists of 30 statements related to various behaviours occurring in partner relationships, which create 3 scales: mutual communication, intimacy and behaviour in a quarrel. In contrast to the scales of intimacy and communication, on the quarrel scale high values indicate particularly negative behaviour. The study of the scales' internal structure points to their satisfactory psychometric parameters; the internal consistency coefficients are as follows: the reliability: .88 for the mutual communication scale, .91 for the intimacy scale, .93 for the quarrel scale and .95 for the sum of the three scales. The reliability of the questionnaire was also checked by the method of repeating the test. Reliability coefficients were found to be favourable for all three scales and their sum. Reliability coefficients were: .68 for the quarrel scale, .74 for the intimacy scale, .83 for the mutual communication scale, and .85 for the sum of the three scales. This questionnaire can be used to diagnose disorders in the relations between the partners (Janicka, 2008).

\section{RESULTS}

\section{INTENSITY OF SYMPTOMS}

The survey with the "Women's Health" Questionnaire allowed symptoms occurring in women during menopause to be evaluated. A comparison of results was performed (Figure 1), referring to the menopausal symptoms in women belonging to three groups: in premenopause, perimenopause and postmenopause.

Most symptoms - and their highest severity are experienced by women in perimenopausal and postmenopausal phases. Women after menopause, compared with other groups of women, report more symptoms considered to be non-specific for menopause, such as depression, memory and concentration disorders, somatic symptoms, but also sexual dysfunctions that can result both from pain ailments during intercourse as well as the loss of interest in sexual intercourse. Women in the perimenopausal phase, more than other groups of women, complain of specific symptoms for menopause, such as vasomotor symptoms and symptoms associated with menstruation, but also of lower attractiveness. It is believed that menopausal symptoms clearly manifest themselves already in women in the "circa-menopausal" stage, and some of them (anxiety, sleep problems) may be at a similar level as in women after menopause. 


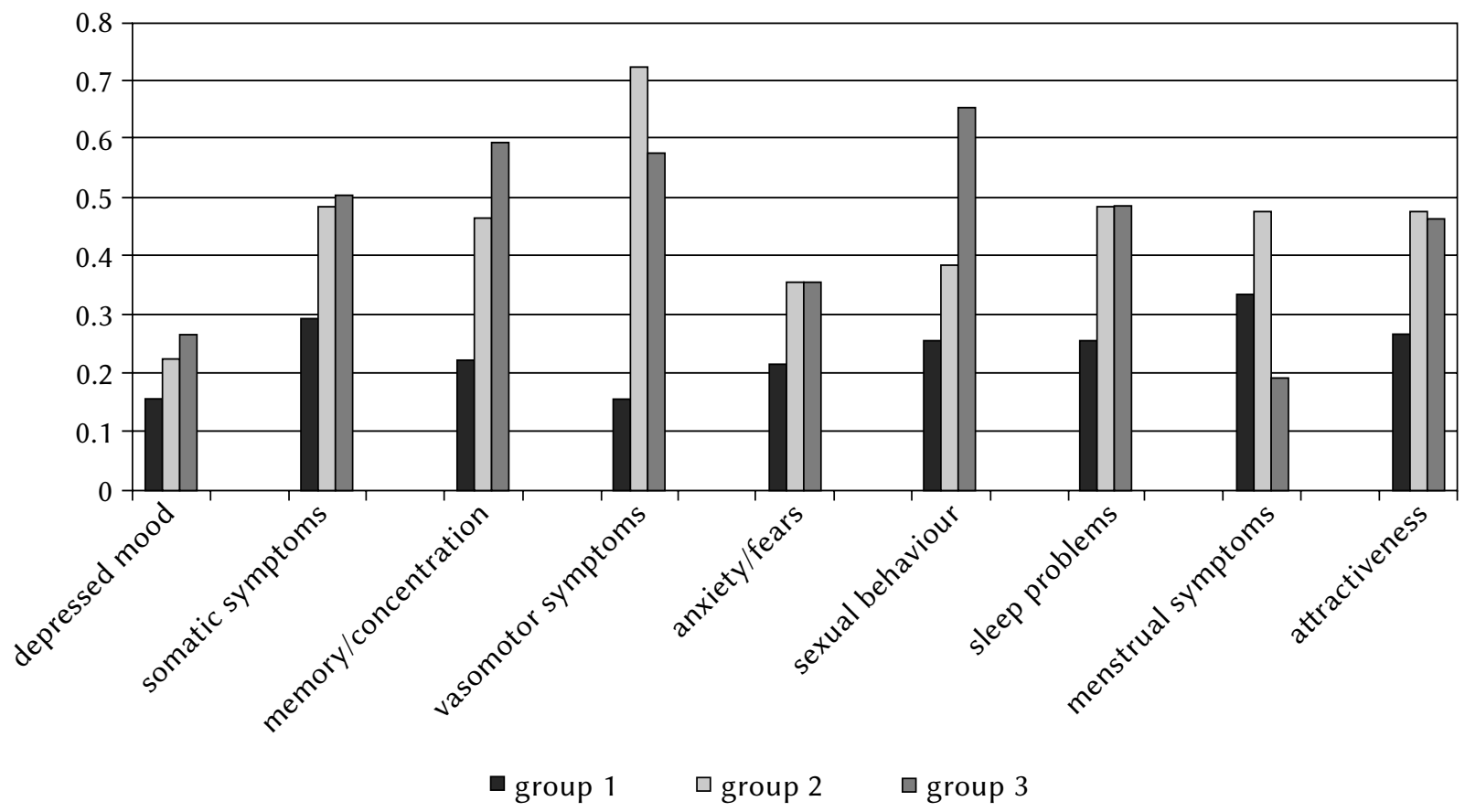

Quality of the relationship of menopausal women

Figure 1. Menopausal symptoms in women during pre- (1), peri- (2), and post- (3) menopause (ANOVA $F(3,197), p<.05)$.

\section{LIFESTYLE, HEALTH AND SYMPTOMS}

The data obtained from the survey allowed us to calculate the percentage of respondents (out of the total number of those surveyed) who lead a healthy lifestyle, are not chronically ill, and are in cohabiting or marital relationships. Most of the participants who were not physically active (52.20\%) were mainly postmenopausal $(59.40 \%)$ and perimenopausal $(57.30 \%)$ women, and therefore those who experience the most severe symptoms (Figure 1). Most of the respondents smoked tobacco $(68.00 \%)$, and this concerns mainly the postmenopausal women $(74.80 \%)$. This group includes most women with chronic diseases (such as arterial hypertension, spinal degeneration, diabetes, osteoporosis, peptic ulcer disease and allergies), which to some extent can explain the more severe somatic symptoms of these women (Figure 1). Comparing the type of relationship of women in the three analyzed age groups, it may be noted that the majority of surveyees $(88.00 \%)$ live in a formal relationship - marriage. The largest percentage of married women is in the postmenopausal group (94.90\%).

\section{COUPLE RELATIONSHIPS AND MENOPAUSAL SYMPTOMS}

Among participants the differences in intensity of menopausal symptoms between women in marital and cohabiting relationships were statistically insignificant. No significant correlations were also identified between the length of the relationship and the ex- perienced menopausal symptoms in premenopausal women. These women, compared with women during perimenopause and postmenopause, experience the fewest symptoms of hormonal changes (Figure 1), and their relationships are likely to be shorter.

The correlation coefficients concerning the length of the relationship and menopausal symptoms for women in postmenopause are presented in Table 1.

For perimenopausal women, the length of the relationship was significant only for sexual behaviour $(r=-.31, p=.007)$. Sexual functioning of women in the "circa-menopausal" phase was better for those in longer relationships. This may be associated with greater acceptance of the changes related to sexual activity. This can foster the perception of symptoms as less intense.

Significant relations between the length of the relationship and the intensity of menopausal symptoms in women in the postmenopausal phase concern depression $(p=.039)$, somatic symptoms $(p<.001)$, memory and concentration $(p=.006)$, vasomotor symptoms ( $p=.025)$, mood disorders $(p=.016)$ and the overall coefficient of menopausal symptoms $(p<.001)$. These symptoms are more severe in women with longer seniority of the relationship. The third group of women manifest most ailments which intensify with the length of the relationship, although these correlations do not apply, as in younger women, to sexual disorders. It is possible that this sphere of activity becomes less important. Older women less likely seek sexual contact, which limits the potential of experiencing sexual dysfunctions related to hormonal changes. 
Table 1

Length of the relationship and menopausal symptoms in postmenopausal women $(N=79)$

\begin{tabular}{|c|c|c|}
\hline $\begin{array}{l}\text { Menopausal } \\
\text { symptoms }\end{array}$ & & $\begin{array}{l}\text { Length } \\
\text { relationship }\end{array}$ \\
\hline \multirow{2}{*}{ Depression } & $r$ & .23 \\
\hline & $p$ & .039 \\
\hline \multirow{2}{*}{ Somatic symptoms } & $r$ & .40 \\
\hline & $p$ & .001 \\
\hline \multirow{2}{*}{$\begin{array}{l}\text { Memory and } \\
\text { concentration }\end{array}$} & $r$ & .31 \\
\hline & $p$ & .006 \\
\hline \multirow{2}{*}{ Vasomotor symptoms } & $r$ & .25 \\
\hline & $p$ & .025 \\
\hline \multirow{2}{*}{ Anxiety } & $r$ & .27 \\
\hline & $p$ & .016 \\
\hline \multirow{2}{*}{ Sexual behaviour } & $r$ & .22 \\
\hline & $p$ & .050 \\
\hline \multirow{2}{*}{ Sleep problems } & $r$ & .15 \\
\hline & $p$ & .178 \\
\hline \multirow{2}{*}{ Menstruation } & $r$ & -.10 \\
\hline & $p$ & .400 \\
\hline \multirow{2}{*}{ Attractiveness } & $r$ & .22 \\
\hline & $p$ & .056 \\
\hline \multirow{2}{*}{ Overall result } & $r$ & .36 \\
\hline & $p$ & .001 \\
\hline
\end{tabular}

\section{QUALITY OF THE RELATIONSHIPS AND MENOPAUSAL SYMPTOMS}

The assessment of the quality of the study participants' relationships was performed using the "Partner Relations Questionnaire". The comparison of the quality of the relationship between the three groups of women is shown in Tables 2 and 3.

Women from the premenopausal and postmenopausal groups are significantly differentiated by the level of intimacy $(p<.001)$ and mutual communication $(p=.024)$. Better coefficients of these dimensions of the relationship's quality characterise women in premenopause, compared to those after menopause (Table 2). The differences also concern women in the perimenopausal and postmenopausal phases. Intimacy was significantly higher in perimenopausal women, in comparison with menopausal women $(p=.003)$. A similar difference applies to mutual communication $(p=.009)$.

The correlations between the quality of the relationship and the menopausal symptoms for women belonging to the three selected groups associated with hormonal changes are presented in Tables 4, 5 and 6.

Among women in the premenopausal phase (Table 4), the dimensions of the relationship's quality correlated with the coefficients for depression and somatic symptoms. Women experiencing more intense symptoms of depression scored higher rates on behaviour in a quarrel - which means more of such negative behaviour in relations with the partner $(r=.36, p=.014)-$ and lower scores in satisfaction with the relationship $(r=-.53, p<.001)$. Intense somatic symptoms were accompanied by more behaviours in a quarrel $(r=.38, p=.010)$, a lower rating of mutual communication $(r=-.32, p=.028)$ and satisfaction with the relationship $(r=-.40, p=.007)$. The higher the total score for menopausal symptoms, the higher were the coefficients corresponding to behaviour in a quarrel $(r=.32, p=.028)$ and the lower the satisfaction with the relationship $(r=-.35, p=.016)$.

For women in the perimenopausal phase (Table 5), the quality of the relationship and the satisfaction with the relationship are of the highest importance for sexual functioning. More intense sexual dysfunctions are accompanied by a higher rate of behaviour in a quarrel $(r=.30, p=.008)$, a lower level of intimacy $(r=-.60, p<.001)$ and poorer satisfaction with the relationship $(r=-.51, p<.001)$. The lower assessment of intimacy coexisted with a higher score on anxiety $(r=-.36, p<.001)$ and feeling unattractive $(r=-.35$, $p=.002$ ). Women experiencing more menopausal symptoms were less satisfied with their relationship $(r=-.36, p<.001)$, which they primarily evaluated as of low intimacy $(r=-.38, p<.001)$.

Among postmenopausal women (Table 6), the most numerous strong correlations with the level of satisfaction with the relationship and its quality's dimensions concern depression symptoms. Strong symptoms of depression are accompanied by more behaviours in a quarrel $(r=.64, p<.001)$, a low level of intimacy $(r=-.47, p<.001)$, a low level of mutual communication $(r=-.48, p<.001)$ and less satisfaction with the relationship $(r=-.57$, $p<.001)$. A poorer intimacy rating is associated with not only a greater intensity of depression symptoms experienced, but also somatic symptoms $(r=-.41$, $p<.001)$, disorders of memory and concentration $(r=-.37, p<.001)$, sex $(r=-.48, p<.001)$ and sleep $(r=-.46, p<.001)$, and a higher overall coefficient of menopausal symptoms $(r=-.51, p<.001)$. More behaviours in a quarrel characterise relationships of women who also observe in themselves somatic symptoms $(r=.35, p<.001)$, anxiety $(r=.33$, $p=.003)$ and menopausal symptoms captured in the overall index $(r=.38, p<.001)$. Lower satisfaction with the relationship coincided with higher rates of anxiety $(r=-.35, p<.001)$ and the sum of menopausal symptoms $(r=-.32, p=.004)$. 
Table 2

Quality of the relationship of women belonging to three groups: premenopausal, perimenopausal and postmenopausal

\begin{tabular}{|c|c|c|c|c|c|c|}
\hline \multirow[t]{2}{*}{$\begin{array}{l}\text { Quality of the relation- } \\
\text { ship }\end{array}$} & \multirow[t]{2}{*}{$\begin{array}{c}\text { Stages of hormonal } \\
\text { changes }\end{array}$} & \multirow[t]{2}{*}{$n$} & \multirow[t]{2}{*}{ Average } & \multirow[t]{2}{*}{$S D$} & \multicolumn{2}{|c|}{$\begin{array}{c}\text { Analysis of variance } \\
\text { (ANOVA) }\end{array}$} \\
\hline & & & & & $F(3,197)$ & $p$ \\
\hline \multirow{3}{*}{ Behaviour in a quarrel } & Premenopause & 46 & 6.41 & 4.74 & \multirow{3}{*}{0.92} & \multirow{3}{*}{.402} \\
\hline & Perimenopause & 75 & 7.07 & 4.71 & & \\
\hline & Postmenopause & 79 & 7.71 & 5.92 & & \\
\hline \multirow{3}{*}{ Intimacy } & Premenopause & 46 & 18.67 & 6.48 & \multirow{3}{*}{8.56} & \multirow{3}{*}{$<.001$} \\
\hline & Perimenopause & 75 & 17.71 & 6.29 & & \\
\hline & Postmenopause & 79 & 14.25 & 6.72 & & \\
\hline \multirow{3}{*}{ Mutual communication } & Premenopause & 46 & 18.70 & 5.92 & \multirow{3}{*}{5.59} & \multirow{3}{*}{.004} \\
\hline & Perimenopause & 75 & 18.64 & 6.56 & & \\
\hline & Postmenopause & 79 & 15.70 & 5.81 & & \\
\hline \multirow{3}{*}{$\begin{array}{l}\text { Satisfaction with the } \\
\text { relationship }\end{array}$} & Premenopause & 46 & 3.72 & 0.96 & \multirow{3}{*}{0.07} & \multirow{3}{*}{.931} \\
\hline & Perimenopause & 75 & 3.65 & 0.78 & & \\
\hline & Postmenopause & 79 & 3.68 & 0.99 & & \\
\hline
\end{tabular}

Table 3

Quality of the relationship of women belonging to three groups: premenopausal, perimenopausal and postmenopausal - multiple comparisons - Tukey’s test

\begin{tabular}{lccc}
\hline Quality of the relationship & Hormonal changes & $p$ \\
\hline \multirow{2}{*}{ Intimacy } & Premenopause & Perimenopause & .707 \\
& & Postmenopause & $<001$ \\
& Perimenopause & Postmenopause & .003 \\
Mutual communication & Premenopause & Perimenopause & .999 \\
& & Postmenopause & .024 \\
\hline
\end{tabular}

\section{DISCUSSION}

One should find that the perimenopausal and postmenopausal phases are particularly difficult for women due to the high intensity of menopausal symptoms, related to the occurrence and severity of hormonal changes (Fuh et al., 2003). However, the decline in oestrogen levels and the changes in the ratio of the hormones resulting from it lead to progressive and irreversible alterations in the organism, which ultimately manifest themselves in the form of aging. Probably because of that, postmenopausal women (also in comparison to women in perimenopause) reported increased intensity of symptoms non-specific to menopause (such as symptoms of depression and somatic symptoms) or more consequences of hormonal changes (e.g. in the form of sexual dysfunctions).
For women in premenopause, the length of the relationship had no relevance for their mental and somatic functioning. Sexual behaviour of women in the "circa-menopausal" phase was better in those with greater length of the relationship. It must be concluded that what is important for sexual activity is the relation which accompanies sex, together with feelings towards the partner, but also the length of the relationship (Birnbaum, Cohen, \& Wertheimer, 2007).

Women in the period immediately preceding menopause (usually experiencing the greatest changes) are "protected" by a stable relationship, and especially its longer seniority contributes to a higher degree of mutual commitment. According to Grabowska (2014), commitment gives a sense of security, allowing one to express one's sexuality more boldly. A long-term partner is one who knows his
Quality of the relationship of menopausal women 


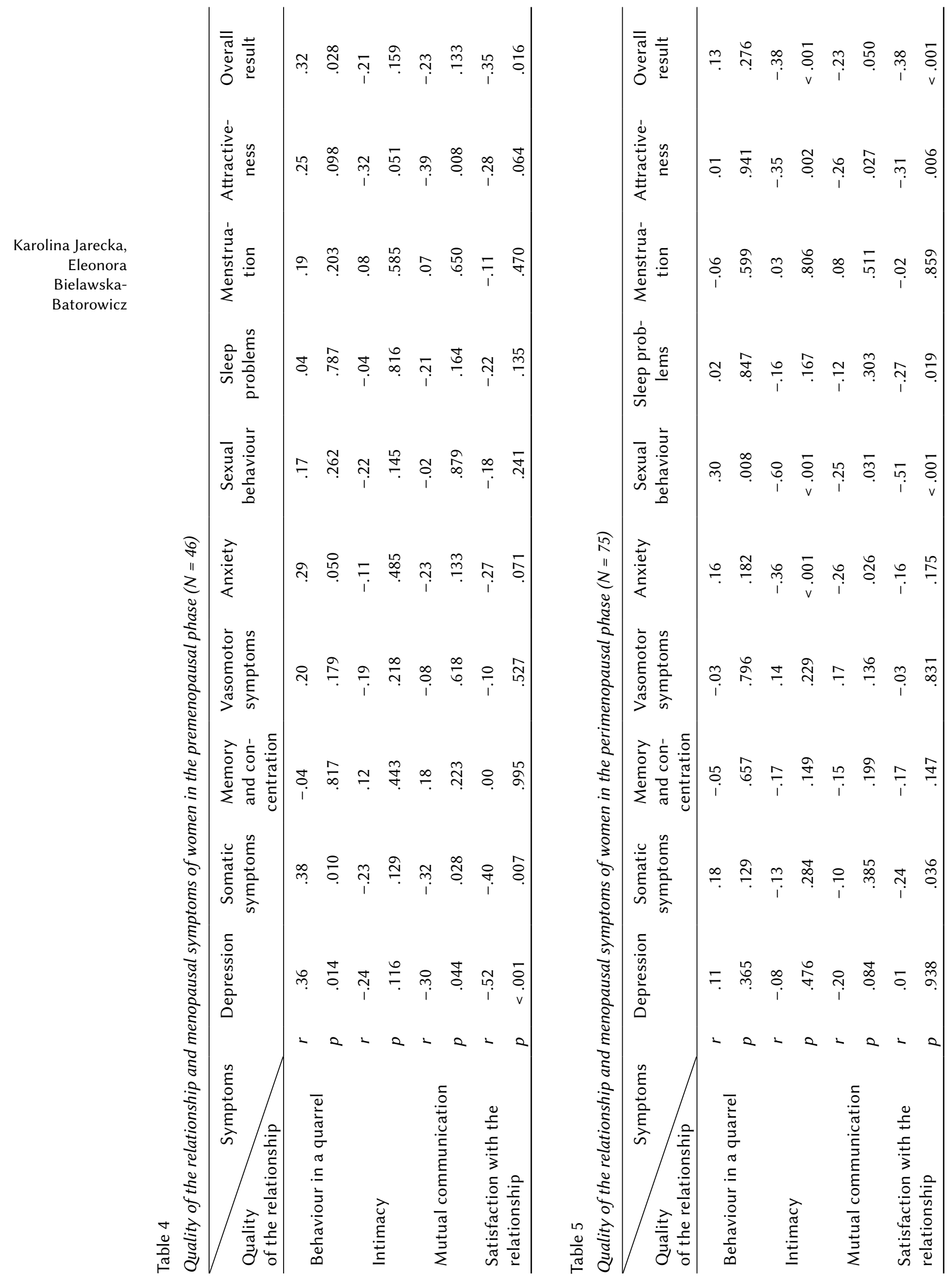


partner, her needs and anxieties, and with whom she can feel safe, including in intimate situations.

The group of women in the postmenopausal phase manifested the greatest number of ailments, which intensify together with the length of the relationship (depression and somatic symptoms, disorders of memory and concentration, anxiety, the sum of menopausal symptoms), whereby these relations did not concern sexual dysfunctions, as is the case with women in perimenopause. The length of the relationship may be linked strongly to age, and with age, the risk of occurrence of somatic symptoms and worse well-being increases. Stagnation and adverse changes associated with the structure of the family threaten long-term relationships more, which may further affect the well-being of women by strengthening their symptoms. Postmenopausal women probably do not expect sexual satisfaction (Skrzypulec-Plinta, Chełmicki, \& Gojdź, 2011; Czyżkowska, Rawińska, \& Lew-Starowicz, 2011), but more attention and positive reinforcements from the partner. Along with the length of the relationship, the need to experience tenderness grows in women, and the partner's readiness to satisfy it may diminish. The period of middle and late adulthood is a time which favours self-concentration and self-realization in roles other than family-related (Grabowska, 2014). Passion, and hence the desire and search for physical intimacy which often leads to sexual acts, is more characteristic for the first stages of the relationship - falling in love and romantic beginnings - than it is for long-term relationships (Sternberg, 2007). Klusmann's studies indicate that the frequency of sexual intercourse and sexual satisfaction are significantly reduced already in the first years of the relationship (Grabowska, 2014). Perhaps the long-term relationship, in which both partners to a lesser degree are drawn to sexual acts, protects women from experiencing sexual dysfunctions associated with hormonal changes.

In postmenopausal women, the quality of the relationship was the most relevant for the experiences related to hormonal changes. In this group, one of the three dimensions of the quality of the relationship - intimacy - proved to be the most significant for menopausal symptoms. A lower intimacy rating accompanied more severe symptoms (depression-related, somatic, disorders of memory and concentration, sex, sleep, the sum of menopausal symptoms). Depression symptoms in postmenopausal women were most strongly and negatively linked to the assessment of the quality of the relationship. A bad relationship with the partner is more often characteristic of women who negatively assess menopause and report more ailments (Barth Olofsson \& Collins, 2000). A study of postmenopausal women showed that a stable interpersonal relationship, such as marriage, has implications for the level of perceived stress (Avis et al., 2004) and probably also decides on

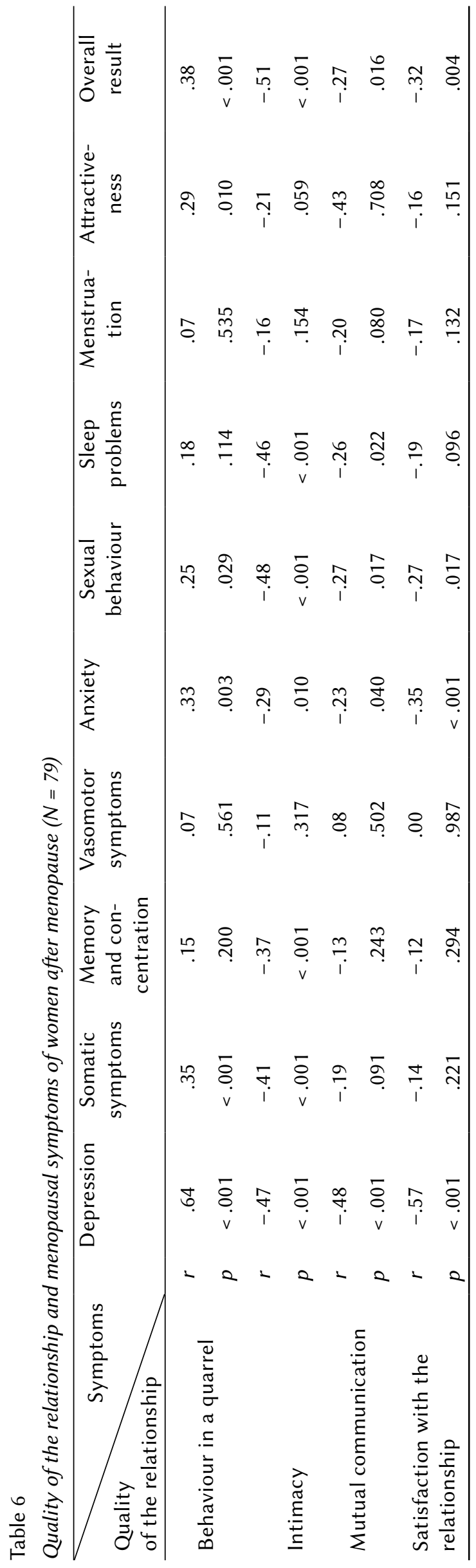

Quality

of the relationship of menopausal women 
Karolina Jarecka, Eleonora BielawskaBatorowicz adapting to the new situation, which is the change in psychosomatic functioning after menopause. The belief that one is loved, important for others, surrounded by care, may mitigate the experienced symptoms (by better coping with them) and contribute to well-being. According to Bacon, the bond with a close person can double the feeling of joy and limit sorrow (Myers, 2007). Women, compared with men, experience negative emotions more often, especially in unsatisfactory relationships. Depression symptoms in women less satisfied with their relationships may result from their tendency to blame themselves for the problems faced, as well as their partners' tendency to withdraw, which in effect charges the female partner emotionally. Women keep conflicts and mutual resentments in the memory longer than their partners do. The vulnerability to depression is higher in women who have an insatiable need for closeness. In addition, their mental and physical health is strongly dependent on the satisfaction with the relations with the partner, especially in relationships with longer seniority (Kaźmierczak, 2008; Janicka, 2012), which more frequently affects elder women.

For women in perimenopause, poorer assessment of the level of intimacy (a dimension of the quality of the relationship) was associated with a higher level of anxiety, more severe sexual dysfunctions and a lower sense of attractiveness. Intimacy describes positive feelings towards the partner, enabling affection, proximity and interdependence (Sternberg, 2007). Its role is particularly important in difficult situations, as it reduces negative emotions, such as anxiety (Taylor \& Sherman, 2007). According to Grabowska (2014), intimacy in a relationship has a positive effect, including for sexual behaviour. It is the degree of intimacy on which the ability to satisfy the sexual needs of oneself and the partner depends, together with taking the initiative as well as the frequency and satisfaction from sexual intercourse. Good marital relations based on good communication, mutual acceptance and having common interests are cited as factors determining good sexual functioning of women during menopause (Ling, Wong, \& Ho, 2008; Jarząbek-Bielecka, SowińskaPrzepiera, \& Pawlaczyk, 2012). Sexual satisfaction correlates with the satisfaction with the relationship, so if one is reduced, the other decreases also (Lew-Starowicz \& Szymańska, 2012). According to McCall and Meston (Stusiński \& Lew-Starowicz, 2012) the feeling of love and emotional bond may increase the level of sexual desire, even in the event of low libido in postmenopausal women. Stereotypes existing in our culture make women feel less attractive with the onset of menopause (Bielawska-Batorowicz, 2006). For women, the sense of external attractiveness is of importance, and a successful relationship provides the experience of approval and adoration by the partner (Lew-Starowicz \& Szymańska, 2012). Women whose relationships with partners are devoid of intimacy are more vulnerable to adverse changes in the perception of their own attractiveness and sexuality (Birnbaum et al., 2007), and thus the incidence and severity of menopausal symptoms may be greater.

In premenopausal women, the relations between menopausal symptoms and the dimensions of the quality of the relationship turned out to mainly concern behaviour in a quarrel. The more frequently women took part in experiencing this kind of behaviour, the worse they felt both psychologically and somatically. The mind and the body are permanently linked, which means that mental trauma is also evident in somatic disorders (Rotschild, 2014). Quarrels with the partner deprive or limit the sense of closeness, intimacy and secure coexistence, which significantly affects the well-being of the woman, intensifies her somatic ailments and worsens the mood.

\section{CONCLUSIONS}

Close interpersonal relationships play a significant role in health behaviours and in adapting to the new situation, which is the change in psychosomatic functioning of women during menopause. Rejection and loneliness, as well as lack of intimacy in relations with the partner, can deepen and prolong the time of experienced ailments. The belief that one is loved, important, understood and surrounded by care may however ameliorate the experienced symptoms through enabling more effective coping with them and thus contribute to well-being.

\section{RefERENCES}

Argyle, M. (2005). Przyczyny i korelaty szczęścia [Causes and correlates of happiness]. In J. Czapiński (ed.), Psychologia pozytywna. Nauka o szczęściu, zdrowiu, sile i cnotach człowieka [Positive psychology. The science of happiness, health, strength and virtues of man] (pp. 165-203). Warszawa: PWN.

Avis, N. E., Assmann, S. F., Kravitz, H. M., Ganz, P. A, \& Ory, M. (2004). Quality of life in diverse groups of midlife women: Assessing the influence of menopause, health status and psychosocial and demographic factors. Quality of Life Research, 13, 933-946.

Barth Olofsson, A. S., \& Collins, A. (2000). Psychosocial factors, attitude to menopause and symptoms in Swedish perimenopausal women. Climacteric, 3, 33-42.

Bielawska-Batorowicz, E. (2006). Psychologiczne koncepcje prokreacji [Psychological concepts of procreation]. Katowice: Wyd. Śląsk. 
Bielawska-Batorowicz, E. (2011). Menopauza i andropauza. Lustrzane odbicie czy różne zjawiska? [Menopause and andropause. Mirror reflection or different phenomena?] In B. Bartosz (ed.), Wymiary kobiecości i męskości. Od psychologii do kultury [The dimensions of femininity and masculinity. From psychology to culture] (pp. 33-56). Warszawa: Wyd. Eneteia.

Bińkowska, M. (2011). Menopauza [Menopause]. In W. Zgliczyński (ed.), Wielka Interna. Endokrynologia. Część 2 [Endocrinology. Part 2] (pp. 609-619). Warszawa: Wyd. Medical Trybune.

Birnbaum, G. E., Cohen, O., \& Wertheimer, V. (2007). Is it all about intimacy? Age, menopausal status, and women's sexuality. Personal Relationships, 14, 167-185.

Bishop, G. D. (2000). Psychologia zdrowia [Health psychology]. Wrocław: Wyd. Astrum.

Cutrona, C. E. (1996). Social support in couples. Marriage as a resource in times of stress. London: Sage Publications.

Czyżkowska, A., Rawińska, M., \& Lew-Starowicz, Z. (2011). Zaburzenia pożądania u kobiet w okresie klimakterium w praktyce klinicznej [Hypoactive sexual desire disorder among women in the climacteric period in clinical practice]. Przeglad Menopauzalny, 6, 448-453.

Farrel, J. F., Hook, J. N., \& Ramos, M. (2015). Humilityand relationship outcomes in couples: the mediating role of commitment. Couple and Family Psychology: Research and Practice, 4, 14-26.

Fuh, J. L., Wang, S. J., Lee, S. J., Lu, S. R., \& Juan, K. D. (2003). Quality of life and menopausal transition for middle-aged women on Kinmen island. Quality of Life Research, 12, 53-61.

Grabowska, M. (2014). Seksualność w związkach małżeńskich [Sexuality in marital relationships]. In I. Janicka \& H. Liberska (eds.), Psychologia rodziny [Family psychology] (pp. 167-184). Warszawa: PWN.

Harwas-Napierała, B. (2012). Zdrowie rodziny w perspektywie psychologicznej [Health of family in a psychological perspective]. In T. Rostowska \& A. Lewandowska-Walter (eds.), Matżeństwo i rodzicielstwo a zdrowie [Marriage, parenthood and health] (pp. 15-25). Toruń: Wyd. Adam Marszałek.

Hunter, M. (1992). The woman's health questionnaire: a measure of mind-aged woman's perceptions of their emotional and psychical health. Psychology and Health, 7, 45-54.

Janicka, I. (2008). Stosunki partnerskie w związkach niemałżeńskich [Partner relations in non-marital couples]. Przegląd Psychologiczny, 1, 37-53.

Janicka, I. (2012). Poczucie dobrostanu u osób poślubionych, kohabitujących i u singli [A sense of wellbeing in married, cohabiting and single people]. In T. Rostowska \& A. Lewandowska-Walter (eds.), Matżeństwo i rodzicielstwo a zdrowie [Marriage, parenthood and health] (pp. 26-53). Toruń: Wyd. Adam Marszałek.

Jarząbek-Bielecka, G., Sowińska-Przepiera, E., \& Pawlaczyk, M. (2012). Aging and sexual activity: gynecological, sexological and psychological aspects. Przeglad Menopauzalny, 6, 487-489.

Kaczmarek, M. (2007). Określenie wieku menopauzy naturalnej w populacji polskich kobiet [Estimation of the age at natural menopause in a population-based study of Polish women]. Przeglad Menopauzalny, 2, 77-82.

Kaczmarek, M. (2008). Zróżnicowanie wieku menopauzy naturalnej wśród polskich kobiet ze względu na historie okresu rozrodczego [Variation in the age at natural menopause among Polish women in relation to their reproductive histories]. Przeglad Menopauzalny, 2, 69-76.

Kamp Dush, C. M., \& Amato, P. R. (2005). Consequences of relationship status and quality for subjective well-brining. Journal of Social and Personal Relationships, 22, 607-627.

Kaźmierczak, M. (2008). Oblicza empatii w relacjach matżeńskich. Perspektywa psychologiczna [Aspects of empathy in marital relations. Psychological perspective]. Gdańsk: Wyd. UG.

King, L., Ells, J., \& Burton, Ch. (2007). Pojęcie dobrego życia - w ujęciu szerokim i wąskim [The concept of the good life - in a wide and narrow spectrum]. In P. Linley \& S. Joseph (eds.), Psychologia pozytywna w praktyce [Positive psychology in practice] (pp. 19-40). Warszawa: PWN.

Lew-Starowicz, Z., \& Szymańska, M. (2010). Zaburzenia seksualne i problemy osobiste kobiet powyżej 45. roku życia [Sexual disorders and personal problems of women aged over 45]. Przeglad Menopauzalny, 6, 381-384.

Ling, D. C., Wong, W. C. W., \& Ho, S. C. (2008). Are post-menopausal women "half-a-man"?: sexual beliefs, attitudes and concerns among midlife chinese women. Journal of Sex \& Marital Therapy, 34, 15-29.

Myers, D. G. (2007). Związki z ludźmi a dobre życie: szukanie równowagi między interesem jednostki i wspólnoty w polityce społecznej [Relationships with people and a good life: the search for balance between the interest of an individual and the community in social policy]. In P. Linley \& S. Joseph (eds.), Psychologia pozytywna w praktyce [Positive psychology in practice] (pp. 389-411). Warszawa: PWN.

Oleś, P. (2000). Psychologia przetomu połowy życia [Psychology of mid-life turn]. Lublin: Towarzystwo Naukowe KUL.

Raport WHO. (2001). Badania nad menopauza w latach 90. [Research on menopause in the 90s]. Łódź: Instytut Medycyny Pracy im. Prof. J. Nofera.

Rotschild, B. (2014). Ciato pamięta. Psychofizjologia traumy i terapia osób po urazie psychicznym [The
Quality of the relationship of menopausal women 
Karolina Jarecka,

Eleonora BielawskaBatorowicz body remembers. Psychophysiology of trauma and treatment of persons with mental trauma]. Kraków: Wyd. UJ.

Schneider, H. P. G., MacLennan, A., \& Feeny, H. (2008). Assessment of health related - quality of life in menopause and aging. Climacteric, 11, 93-107.

Skrzypulec-Plinta, V., Chełmicki, A., \& Gojdź, K. (2011). Czy spadek libido po menopauzie ma podłoże hormonalne? [Does libido decrease during menopause have hormonal background?]. Przegląd Menopauzalny, 4, 334-337.

Stachoń, A. J. (2013). Ocena odczuwania wybranych objawów w zależności od fazy klimakterium i charakteru menopauzy [Feeling of the selected climacteric symptoms depending on the climacteric phase and type of menopause]. Przeglad Menopauzalny, 4, 315-320.

Sternberg, R. J. (2007). Dwuskładnikowa teoria miłości [Two-component theory of love]. In R. J. Sternberg \& K. Weis (eds.), Nowa psychologia mitości [The new psychology of love] (pp. 275-296). Taszków: Moderator.

Stusiński, J., \& Lew-Starowicz, Z. (2012). Funkcjonowanie seksualne kobiet w średnim wieku - przegląd piśmiennictwa [Sexual functioning of middle-aged women: a literature review]. Przegląd Menopauzalny, 2, 87-92.

Taylor, S., \& Sherman, D. (2007). Psychologia pozytywna i psychologia zdrowia: owocny związek [Positive psychology and health psychology: a fruitful liaison]. In P. Linley \& S. Joseph (eds.), Psychologia pozytywna w praktyce [Positive psychology in practice] (pp. 194-210). Warszawa: PWN.

Tobiasz-Adamczyk, B. (2000). Wybrane elementy socjologii zdrowia i choroby [Selected elements of the sociology of health and illness]. Kraków: Wyd. UJ.

Waite, L. J., \& Gallagher, M. (2000). The case for marriage. why married people are happier, healthier, and better off financially. New York: Random House. 